Article

\title{
A Study on Growth Engines of Middle Market Enterprise (MME) of Korea Using Meta-Analysis
}

\author{
Minseo Kim ${ }^{1}$, Seongbae Lim $^{2}$ and Yeong-wha Sawng ${ }^{3, *}$ \\ 1 College of General Education, Seoul Women's University, Seoul 01797, Korea; mskim@swu.ac.kr \\ 2 Greehey School of Business, St. Mary's University, San Antonio, TX 78228, USA; slim1@stmarytx.edu \\ 3 William F. Miller School of Management of Technology, Konkuk University, Seoul 10223, Korea \\ * Correspondence: sawng@konkuk.ac.kr
}

Citation: Kim, M.; Lim, S.; Sawng, Y.-w. A Study on Growth Engines of Middle Market Enterprise (MME) of Korea Using Meta-Analysis. Sustainability 2022, 14, 1469. https:// doi.org/10.3390/su14031469

Academic Editor: Wen-Hsien Tsai

Received: 20 December 2021

Accepted: 24 January 2022

Published: 27 January 2022

Publisher's Note: MDPI stays neutral with regard to jurisdictional claims in published maps and institutional affiliations.

Copyright: () 2022 by the authors Licensee MDPI, Basel, Switzerland. This article is an open access article distributed under the terms and conditions of the Creative Commons Attribution (CC BY) license (https:// creativecommons.org/licenses/by/ $4.0 /)$.

\begin{abstract}
The purpose of this study is to comprehensively review previous studies and discover implications for the sustainable growth engines of middle market enterprise (MME) of Korea using meta-analysis. Since Germany's hidden champion companies are considered as benchmarking targets because their economic environment and size are similar to those of Korean MMEs, a meta-analysis was conducted on the previous studies of them. As a result of integrating the effect sizes of input and output factors according to the process of the Program Logic model from the viewpoint of dynamic capabilities, 198 in Germany and 229 in Korea were derived. It was found that, unlike Korean companies, the number of skilled workers, labor productivity, CEO experience, and Innovation activities within the firm had a significant impact on Germany's hidden champion companies. In addition, industry and region-oriented innovation networks and family businesses were identified as important variables. Meta-analysis collects a large number of individual studies in order to integrate the results and statistically assess the data. As a result, it will be used as basic data for developing models for academic research in the future. In addition, it will provide implications for sectors in which Korean MMEs should concentrate their efforts in order to create an innovative ecosystem.
\end{abstract}

Keywords: growth engine; sustainable growth; middle market enterprise of Korea; hidden champion; meta-analysis

\section{Introduction}

Most markets in highly developed open economies, innovation is a key driver of competition [1]. SMEs (small- and medium-sized enterprises) need to develop capabilities and management practices not only to keep pace with technological change but also to gain competitive advantages from innovation, allowing them to compete with large firms [1]. In a time when the pandemic caused by COVID-19 has caused economic downturns in countries around the world and paradigm shifts in industries, as with recent times, firms are required to innovate to overcome the crisis [2]. However, technological innovation does not always succeed and often fails because innovation activity is uncertain. Nevertheless, experts predict that COVID-19 will bring about bigger impacts than the 2008 global financial crisis and that if it is not properly responded to, firms may face long-term difficulties. Recently, innovation research has explained how firms cope with the economic fallout of the pandemic and how innovation processes are structured and conducted [3]. The research suggests that firms respond to emerging challenges by accelerating digitization $[4,5]$, rethinking corporate practices [5-7], or developing frugal solutions [3,8]. Additionally, technology innovation based on partnerships will be a key factor in promoting a virtuous cycle of national economic growth and in creating a firm's sustainable growth and positive economic performance $[9,10]$.

During the 2008 economic crisis, Germany, a manufacturing powerhouse, overcame the crisis by strengthening the innovation capabilities of small- and medium-sized firms 
(SMEs), which are the center of the German economy and society, and it is being talked about as a representative success story. Germany established the ¡ Mittelstand 4.0ๆ strategy for the growth of SMEs and established a strategy to convert production processes to digital ones; to implement this strategy, the Federal Ministry for Economic Affairs and Energy (BMWi) of Germany input 28.84 million euros (about 37 billion in KRW) in 2016 and 48.31 million euros (about 62 billion in KRW) in 2017. Germany's bold investment decision was made because Germany judged that the role of flexible and fast SMEs/middle market enterprises was most important to overcome the rapidly changing crisis and respond to technologies and markets.

South Korea has also pursued changes by benchmarking the case of Germany. Germany has experienced a history of division, as with South Korea, has an SME-type industrial structure centered on manufacturing, and has many similarities to the South Korean economy in that its economy is a global-oriented economy with high external dependencies [11]. In addition, similar to South Korea, Germany has an export-oriented economy and a large firm-led SME-type industrial structure. As such, the similarities, such as the fact that Germany's SME size is similar to that of South Korea, the fact that both countries put emphasis on human resources due to the lack of resources, and the fact that both countries put emphasis on manufacturing and export-oriented economic policies, are reasons why South Korea benchmarks Germany for SME policies [12].

Thus far, South Korea has achieved economic growth centered on manufacturing industries such as automobiles, semiconductors, and steel, but problems due to the sluggish manufacturing industries have been constantly raised. In addition, the trickle-down effects brought about by large-firm-centered growth and the global crisis of COVID-19 overlapped the problems caused by the polarization of large firms and SMEs, exacerbating the growth stagnation of small- and medium-sized and middle market enterprises $[13,14]$. If a large firm system is selected in the early stages of economic development, it will be possible to accelerate the pursuit of advanced countries through the imitation and learning of overseas advanced experiences and technologies, thanks to the economy of scope and the economy of scale. However, it will intensify the problem of polarization in income and resource distributions and structuralize the large-firm-first principle, leading to the inhibition of the growth of SMEs and middle market enterprises. Since the 1980s, the polarization of the South Korean economy has already been confirmed by the fact that cases of upward movement from the start-up to the SME-middle market enterprise to the large firm and corporate group are very rare [13]. The polarization was further exacerbated by the social and environmental event termed COVID-19.

Arguments have been raised by major research institutes that in order to overcome the foregoing, the environmental opportunity from the reorganization of industrial paradigms due to digitalization, as with that of recent times, should be seized to utilize SMEs and middle market enterprises as new growth engines. In particular, in preparation for the post-Corona era, the importance of nurturing middle market enterprises, which are a firm group similar to the hidden champions among German Mittelstand firms, is being emphasized again. Hidden champion is a term that first appeared in a book conducted by Simon (1990) [15]. The term was used first as a title of a publication in a scientific German management journal to describe a small firm in Germany. In order to be considered a hidden champion, a company must meet the following conditions: (1) Number one, two, or three in the global market, or number one on the company's continent, determined by market share, (2) revenue below USD 5 billion, and (3) low level of public awareness [16]. Since middle market enterprises are more stable than SMEs in internal resources, capabilities, and technical skills, these firms should be intensively fostered to construct a stable economic structure and secure competitive advantages. In South Korea, the legal concept of middle market enterprises was enacted in 2011, and currently, there are 4468 middle market enterprises. Despite that the share of these firms in the industrial structure is very small, as they account for only $0.1 \%$ of all firms, middle market enterprises play a much more important role in economic growth compared to SMEs to the extent that the sales of middle 
market enterprises are 639 trillion won, accounting for $14.5 \%$ of the total domestic firms' sales, and their export amount is 85.1 billion dollars, which is $17.2 \%$ of the total export amount of South Korea (www.ahpek.or.kr, accessed on 23 August 2021). In addition, since middle market enterprises play the role of the waist of industry, fostering them can create a pot-shaped economic structure with a strong backbone and a healthy industrial ecosystem. This will enhance not only firm competitive power but also national competitive power so that the present economic problems can be fundamentally solved.

However, since the South Korean policy paradigm classifies firm types (large firms, middle market enterprises, SMEs) based on the sizes of the firms to implement regulations and support according to the firm types, policy and institutional support for middle market enterprises are much more insufficient compared to SMEs. In addition, if a firm grows up from an SME and is judged to be a middle market enterprise, that firm will not receive the legal and institutional support it has received thus far. Therefore, middle market enterprises suffer from difficulties in procuring human resources and funds that they have received since they were SMEs [17]; some competitive SMEs show the "Peter Pan syndrome" in which they avoid growth, and the phenomenon of a return to SMEs is appearing. Consequently, long-term growth stagnation is repeated (http:/ / www.kmmei.re. $\mathrm{kr}$, accessed on 7 July 2021).

Although various issues related to the growth of middle market enterprises in South Korea have been raised, studies on such issues are insufficient because the legal basis for middle market enterprises was enacted in 2011. In addition, since most studies have applied the topics that had been addressed in SME studies to middle market enterprise studies, the characteristics of middle market enterprises, such as their growth paths, investment status, and innovation capability, cannot be reflected, and there are limitations in deriving core factors for growing into global hidden champions. Therefore, this study intends to identify the core factors of the growth of German hidden champion firms shown in previous studies through meta-analysis and to present academic and practical implications through comparison analysis with domestic middle market enterprises.

\section{Literature Review}

\subsection{Middle Market Enterprises (MMEs) in South Korea}

The legal basis for the middle market enterprises (MMEs) in South Korea was prepared through the amendment of the Industrial Development Act (March 2011) and the enforcement ordinance of the same law (1 July 2011) in 2011. Before the foregoing, there was no legal concept of MMEs in the dichotomized industrial structure in which firm groups were classified into SMEs and large firms, defined according to the Framework Act on Small and Medium Enterprises. Therefore, in previous studies, MMEs have been diversely and arbitrarily defined within a certain range that exceeds the scope of SMEs based on capital, sales, or employees.

After the concept of MMEs was introduced in 2011, there were a total of 5007 MMEs in South Korea as of 2018. Although they account for only $0.7 \%$ of the total number of firms, their share in the economy was large, to the extent that they accounted for $21.5 \%$ of sales, $21.5 \%$ of exports, and $21.3 \%$ of employment of entire firms (https:/ /www.fomek.or.kr, accessed on 22 July 2021). MMEs in South Korea have continued to grow and are positioned as the central axis of the industrial ecosystem in charge of "the waist of the industry". Additionally, they are evaluated to be of the size equipped with the "flexibility and speed" that enable the most active responses to changes in global industrial paradigms since they are more stable than SMEs and more flexible and speedy than large firms [18].

In particular, the importance of innovative and strong MMEs that have unique agility and do not hesitate to take on challenges is being emphasized in the recent time of great changes in the industrial landscape. Therefore, the South Korean government has established various customized policies considering the sizes and characteristics of firms and has been striving to create a sound industrial ecosystem and strengthen the competitive power of industries through an industrial cooperation model led by MMEs. It is necessary 
to strengthen the bridging roles of middle market enterprises so that SMEs, which account for $94.8 \%$ of all South Korean firms and about $88 \%$ of employees, can grow into large firms equipped with global competitive power.

Nevertheless, SMEs and MMEs in South Korea are still experiencing growth stage stagnation and growth rate retardation. Starting from 10 billion won in sales, the number of firms rapidly decreases, and there are few firms growing into each of the stages of SMEs $\rightarrow$ MMEs $\rightarrow$ large firms. The number of firms that grew from SMEs to MMEs was 96 as of 2018, but the number of firms that returned to SMEs due to declining sales was 89. Therefore, the actual increase in the number is very small, around 10 per year. In addition, the number of firms that have grown from an MME to a large firm since 2014 is only 5. Additionally, the growth rate is low compared to that of a "unicorn", as shown in Figure 1. The slow emergence of SMEs and MMEs equipped with global competitive power is a very dangerous signal for the South Korean economy and industrial structure [19].

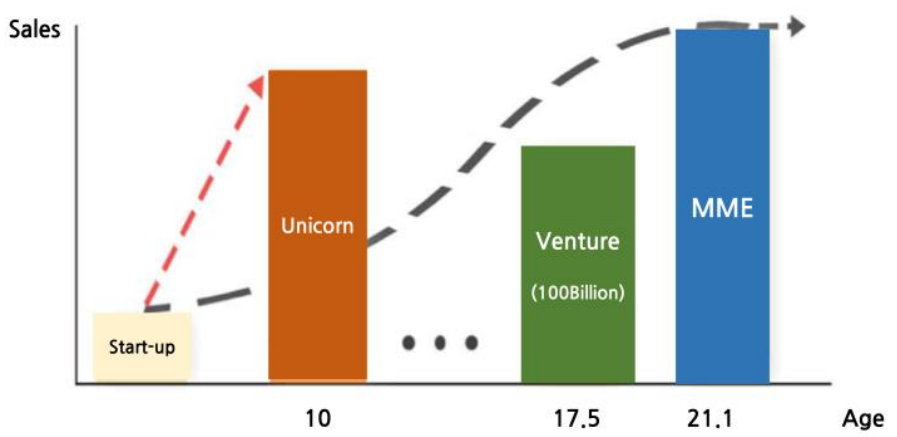

Figure 1. Growth rate of MMEs in Korea (The Government of the Republic of Korea, 2020).

Since MMEs have different characteristics from large firms or SMEs in not only the sizes of firms but also internal resources, capabilities, management strategies, investment activities, and growth paths, in-depth studies on the internal resources and capabilities and the innovative strategic activities of MMEs are necessary [20].

\subsection{Mittelstand and Hidden Champion}

The reason Germany has become an economic powerhouse that leads the European economy today is not only its diverse internal and external ecosystem environment, such as domestic public-private partnerships, market expansion due to the European Union, excellent logistics and transportation networks, and ideal geographical conditions linking Eastern and Western European countries, but also many strong global SMEs. Germany, as with Korea, is a country with an export-oriented economy and has an economic structure in which large firms lead the industry but SMEs strongly support large firms. In Germany, domestic SMEs are collectively called Mittelstand, and the scope is determined according to sales and employees. The IFM Bonn defines small- and medium-sized firms (SMEs) by referring to quantitative criteria, i.e., annual turnover ( $\leq$ EUR 50 million) and the number of employees (<500 employees) (https: / / en.ifm-bonn.org, accessed on 7 July 2021) (Table 1). The quantitative standards are similar to those for South Korean SMEs, but IFM Bonn includes the concept of family firms in ownership and governance as well as quantitative regulations. This is different from South Korean SMEs.

Table 1. SME definition of the IfM Bonn (https:/ / en.ifm-bonn.org (accessed on 7 July 2021)).

\begin{tabular}{ccc}
\hline Firm Size & No. of Employees & Turnover in EUR p.a. \\
\hline Micro & Up to 9 & up to 2 million \\
Small & Up to 49 & up to 10 million \\
Medium-Sized & Up to 499 & up to 50 million \\
SME (overall) & Under 500 & up to 50 million \\
\hline
\end{tabular}


Similar to South Korea, SMEs (kleineund mittlere unternehmen) in Germany account for $99.8 \%$ of all firms in number and $64.1 \%$ of the employed population (Table 2 ).

Table 2. Comparison of SME characteristics.

\begin{tabular}{lccc}
\hline & & Germany (2018) & South Korea (2018) \\
\hline SMEs & No. of Companies & $3,476,814(99.8 \%)$ & $6,638,694(99.9 \%)$ \\
SMEs & Ratio of Employment in the Entire Industry & $64.1 \%$ & $83.1 \%$ \\
SMEs & Ratio of Sales in the Entire Industry & $58.6 \%$ & $48.5 \%$ \\
SMEs & Ratio of Export in the Entire Industry & $15.93 \%$ & $34.1 \%$ \\
\hline
\end{tabular}

Similar to Korea, Germany has an economic structure led by large firms, but German cooperative SMEs are different from South Korean SMEs in that they are global SMEs ranked 1st to 3rd in the world market and can exert equal bargaining power with large firms [11]. As such, the win-win structure with large firms ultimately supports the stable economic structure of the German economy. These firms are called "hidden champions", and this is also a reason why German SMEs are recognized globally for their competitive power. The term "hidden champions" has been explored by Simon since the beginning of the 1990s, and it is used to describe SMEs with high world market share. According to the assumptions of Simon's concept, hidden champions share the following characteristics $[1,16]$ :

(1) A hidden champion takes a top-3 position on the global market or the first position in Europe or on its continent-its market position is primarily dependent on its market share (or on its relative share).

(2) Its revenue does not exceed five billion euros.

(3) It has got little popularity and leads a more or less hidden existence away from the public eye.

According to Simon.Kucher and Partners (2021), Germany has the largest number of hidden champion firms at 1573 and shows an unrivaled status to the extent that the gap from the United States, which is in the second place, is very large. On the other hand, it is reported that only 22 hidden champion firms exist in South Korea.

Therefore, many major studies in South Korea commonly argue that, in order to foster South Korean hidden champion firms, it is necessary to foster MMEs that have the most similar firm characteristics to hidden champions [11,12] since German hidden champion firms are close to large firms based on South Korean standards; MMEs that act as the waist between SMEs and large firms are highly likely to grow into future hidden champions.

A major characteristic mentioned as a success factor of the German hidden champion firms shown in previous studies is that they are long-lived firms. The technological accumulation and source technologies of skilled manpower can cause innovation and consequently launch products with market competitiveness. This can be said to be the result of continuous technical education and consulting under an excellent entrepreneurial spirit [11,21,22]. Kim (2014) emphasized that there are many differences in management systems, strategies, and management environments as well as management philosophies and management perspectives between German and South Korean SMEs; parts that can be benchmarked should be strategically taken [11].

\subsection{Dynamic Capabilities of Middle Market Enterprise}

In a rapidly changing environment, to actively respond to the environment, thereby achieving sustainable growth, firms need the ability to make organizational capabilities that are unique assets of them and internally and externally integrate, construct, and reorganize the organizational capabilities, that is, an ability of an upper concept to change routines, processes, and capabilities [23]. The ability to achieve innovative and new competitive advantages despite the path dependence and market position and dynamic processes are necessary. The concept of dynamic competency has been defined diversely by scholars. It is sometimes classified into capabilities but is also defined as a process or routine. With 
a strategic management model focusing on efficiency, Teece and Pisano (1994) described dynamic competency in three dimensions: positions, paths, and process [1,23].

"Positions" refer to the diverse resources currently possessed by the firm that constitute processes and, thereby, can provide competitive advantages; financial, technical, intellectual, organizational, and market assets. Excellence in this field is an element that lays the foundation for strategic and operational management and determines the company's competitive advantages. The concept of "path" refers to the path the firm has taken thus far, which affects the decision of the firm's strategic alternatives. It is formed based on what happened in the past and creates a dynamic learning process in that the knowhow accumulated in the past and present will be used more efficiently hereafter. Inhouse research and development $(R \& D)$ can therefore be an essential prerequisite for a firm's "absorbing capacity", which is, the ability to recognize, assimilate, and apply new knowledge [1,24]. In addition, cooperative preparation and openness to external sources of knowledge are also other relevant means of capacity accumulation. A "process" is a pattern of business methods or execution of a firm, and it means all intra-organizational interactions between different functions and departments and inter-organizational relationships with partners outside the company, particularly customers and suppliers. The process is affected by the position and path the firm has.

Recent studies of hidden champions have shown that processes, positions, and paths are drivers of the hidden champions' success and are important elements when searching for lessons that can be learned by other firms [1,25-28].

Therefore, this study intends to compare South Korean middle market enterprises and German hidden champion firms in terms of processes, positions, and paths. In addition, this study will analyze the relationship between dynamic capabilities and performance to present strategic implications for developing the growth strategies of South Korean middle market enterprises.

\section{Materials and Methods}

\subsection{Criteria for Selecting Studies and Data Collection}

The first steps in this meta-analysis are the retrieval and selection of studies. We reviewed related studies on websites that provide academic information. Since this study aims to verify the core elements that have induced the growth of hidden champion firms in major advanced countries such as Germany and the core competencies of MMEs in South Korea, both domestic and overseas data were reviewed.

In the case of overseas data, the original data of studies conducted with the German Mittelstand were collected. In particular, since hidden champion firms mean strong small firms with innovative capabilities among Mittelstand firms, the data were mainly collected from studies that empirically analyzed those firms. Major sites at which the original texts were searched for were Proquest, EBSCo, and ScienceDirect. The data were searched for at these sites with keywords "Mittelstand", "Hidden champion", "Germany", "SME", "Innovation", and "Success". When searching, data types were limited to scholarly journals and studies, and only those studies that were written in English were extracted. A total of 3227 documents were retrieved, but after excluding overlapping studies and checking the contents of the abstracts, a total of 139 studies suitable for the purpose and scope of this study were selected, and a DB consisting of the variables used in these studies was constructed.

In the case of domestic data, research studies on "innovative SMEs" and "middle market enterprises" were collected from major original text providing source websites such as KISS, KCI, and DBpia because, since the definition of middle market enterprises was established in 2011, similar firm groups could correspond to innovative SMEs in the literature prior to 2011. A total of 512 documents were retrieved, but after excluding overlapping studies and checking the contents of the studies, only empirical studies were selected to construct a DB. 


\subsection{Structure of Variables}

In general, the logic model is a systematic and visual method for understanding and sharing program resources, activities, changes, and results, and it consists of Input $\rightarrow$ Activities $\rightarrow$ Outputs $\rightarrow$ Outcomes (Short, Medium, Long) (Figure 2). In this study, the sizes of the effects of variables recoded according to the process consisting of Input $\rightarrow$ Innovation Activities $\rightarrow$ Innovation Outcome were combined. According to the logic model process, a total of 198 effect sizes were derived in the case of overseas studies and 229 were derived in the case of domestic studies.

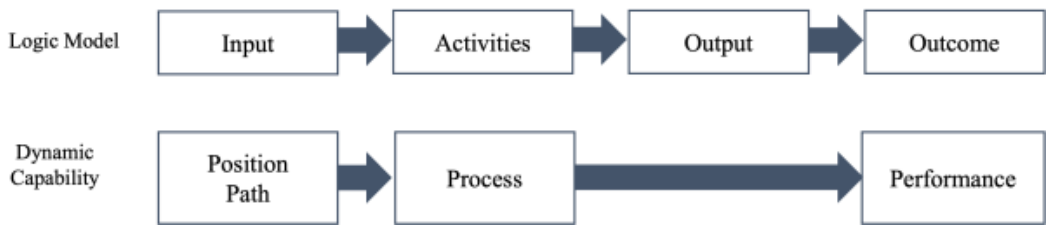

Figure 2. Structure of variables.

Input factors were divided into positions and paths from the viewpoint of dynamic firm capabilities. Positions are firm positions and include technical assets, financial assets, and market structure assets owned by firms. In addition, Teece's study included human capital in the paths because knowledge is inherent not only in equipment and products but also in humans, but this study included it in positions. Positions also include entrepreneurial features from managerial and organizational perspectives. Paths include the innovation orientation and innovation competency of firms that provide path dependency and technological opportunities. It also includes investment in R\&D expenses for innovation. As for the factor innovation activities, $R \& D$ activities affected by the position and path of the firm were redefined as the process dimension of Teece. However, there were some studies that included R\&D cost, open innovation, and in-house innovation as activity factors. Innovation outcomes were divided into financial and non-financial performances (e.g., market performance, new product development, royalty revenue, study performance). The operational definitions of input factors are as shown in Appendix A.

Variables mainly used in the studies in South Korea and those in Germany were compared (Table 3). According to the results, the geographic locations of German hidden champion firms, whether they are family firms or not, and their market shares were used as major variables. In addition, the variable entrepreneurial characteristics were used as an important variable in studies in Germany, but it was not used in domestic studies. The foregoing is judged to have reflected the fact that studies on entrepreneurial characteristics perceived that entrepreneurial characteristics are important in start-up firms in their early stage and SMEs, but the characteristics of managers who pursue efficiency are important in mature firm groups such as MMEs.

In view of the differences in variables, it is assumed that the growth engines of Germany's hidden champions and South Korea's MMEs will be different. 
Table 3. Variable in domestic and foreign literature.

\begin{tabular}{|c|c|c|c|c|}
\hline \multicolumn{3}{|c|}{ Division } & $\begin{array}{c}\text { Overseas } \\
\text { Size }\end{array}$ & Domestic \\
\hline $\begin{array}{l}\text { Dynamic } \\
\text { Capabilities }\end{array}$ & Firm Position & Resource & $\begin{array}{c}\text { Size } \\
\text { Age } \\
\text { Location } \\
\text { Industry } \\
\text { Credit } \\
\text { Export } \\
\text { Family firm } \\
\text { Market share }\end{array}$ & $\begin{array}{l}\text { Size } \\
\text { Age } \\
\text { Location } \\
\text { Industry } \\
\text { Export } \\
\text { Market share }\end{array}$ \\
\hline $\begin{array}{l}\text { Dynamic } \\
\text { Capabilities }\end{array}$ & Firm Position & Employee & $\begin{array}{c}\text { Number of employees } \\
\text { Human capital } \\
\text { Labor productivity }\end{array}$ & Number of employees \\
\hline $\begin{array}{l}\text { Dynamic } \\
\text { Capabilities }\end{array}$ & Firm Position & Finance & $\begin{array}{c}\text { Financial condition } \\
\text { Subsidy }\end{array}$ & $\begin{array}{c}\text { Financial condition } \\
\text { Subsidy }\end{array}$ \\
\hline $\begin{array}{l}\text { Dynamic } \\
\text { Capabilities }\end{array}$ & Firm Position & Entrepreneurial & $\begin{array}{l}\text { Education } \\
\text { Experience } \\
\text { Gender }\end{array}$ & \\
\hline $\begin{array}{c}\text { Dynamic } \\
\text { Capabilities }\end{array}$ & Innov & on path & $\begin{array}{l}\text { Innovation orientation } \\
\text { Innovation competency } \\
\text { Innovation expenditure } \\
\text { Open Innovation } \\
\text { In house Innovation } \\
\text { R\&D } \\
\end{array}$ & $\begin{array}{l}\text { Innovation orientation } \\
\text { Innovation competency } \\
\text { Innovation expenditure } \\
\text { Open Innovation }\end{array}$ \\
\hline $\begin{array}{l}\text { Dynamic } \\
\text { Capabilities }\end{array}$ & Innovation $\mathrm{P}$ & ess: Activities & $\begin{array}{c}\text { Product Innovation } \\
\text { Process Innovation } \\
\text { Technology Application } \\
\text { R\&D cost } \\
\text { R\&D employment } \\
\text { Open Innovation }\end{array}$ & $\begin{array}{c}\text { R\&D cost } \\
\text { Open Innovation } \\
\text { In house Innovation }\end{array}$ \\
\hline Innovation & come: Financia & erformance & $\begin{array}{l}\text { Growth: Sale, Total asset, } \\
\text { Revenue, Employee, Gross } \\
\text { earnings } \\
\text { Efficiency: Asset turnover, } \\
\text { internal rate of return, Labor } \\
\text { productivity }\end{array}$ & $\begin{array}{l}\text { Growth: Sale, Total asset, Revenue, } \\
\text { Employee, Gross earnings } \\
\text { Efficiency: Asset turnover, internal } \\
\text { rate of return, Labor productivity, } \\
\text { Net profit, Operating profit, Sales } \\
\text { per employee }\end{array}$ \\
\hline Innovation $\mathrm{O}$ & me: Non-finan & Performance & $\begin{array}{l}\text { Product innovation output } \\
\text { Process innovation output } \\
\text { Innovation success } \\
\text { New product development }\end{array}$ & $\begin{array}{l}\text { Product innovation output: New } \\
\text { product development, Product } \\
\text { Improvement } \\
\text { Process innovation output: Process } \\
\text { Improvement } \\
\text { Innovation success } \\
\text { Patent application }\end{array}$ \\
\hline & nber of Effect si & & 198 & 229 \\
\hline
\end{tabular}

\section{Method of Meta-Analysis}

\subsection{Coding}

For the coding and analysis of the effect size, we used the Comprehensive Metaanalysis (CMA) 3.0 program. Since the consistency of input and output factors should be secured for meta-analysis, the effect sizes reported in various forms in many studies should be integrated into one type before analysis. A total of 36 studies that fit the purpose of this study were finally selected, similar terms were recoded, and input and output factors were organized (Appendix B). The relationship between input and activity is expressed as IA, and the relationship of input-activity-performance is expressed as IAP. 


\subsection{Effect Size Calculation and Transformation}

Meta-analysis is a comprehensive analysis method to analyze various research results of individual studies with the same subject systematically and quantitatively [29]; it began with Glass, Rosenthal, Hunter, Schmidt in the 1970s and has been developed into a statistical method of "analysis of analysis" to comprehensively analyze existing research results today [30].

For meta-analysis, the effect sizes reported in various forms in many studies should be integrated into one type before analysis. This study analyzed Pearson's product moment correlation coefficient $r$, which indicates a linear relationship between two variables. Since the correlation coefficients reported by individual studies may have biases indicating asymmetric distributions, they were converted into Fisher's $\mathrm{Z}$ to calculate the average effect size [31].

As for the concrete method for this procedure, first, to integrate the effect sizes, the T value, the $F$ value, and the regression coefficient $(\beta)$, which are not reported as Pearson correlation coefficients, are converted into $r$ values using the following formula according to a study conducted by Wolf (1986) [32].

$$
\begin{gathered}
r=\sqrt{\frac{t^{2}}{t^{2}+d f}} \text { or } r=\sqrt{\frac{t^{2}}{t^{2}+n_{1}+n_{2}-2}}(d f: \text { degree of freedom }) \\
r=\sqrt{\frac{F}{F+n_{1}+n_{2}-2}}
\end{gathered}
$$

To minimize the asymmetric bias of the Pearson's product moment correlation coefficients, the effect size was calculated after converting $r$ to Fisher's Z [31]. In a meta-analysis, the larger the number of samples, the more reliable and accurate the effect size. Therefore, larger weights are given in studies with a large number of samples according to the inverse weight $\left(W_{i}\right)$ and the weighted mean $(M)$.

$$
W_{i}=\frac{1}{V_{z}} \quad M=\frac{\sum_{i=1}^{k} W_{1} Y_{i}}{\sum_{i=1}^{k} W_{i}} \quad\left(Y_{i}: \text { Effect size }\right)
$$

The effect sizes, calculated as Fisher's Zs, are converted back to the original Pearson's product moment correlation coefficients before being reported for ease of understanding and interpretation $[31,33]$.

\section{Verification of Publication Bias and Homogeneity}

\subsection{Publication Bias}

Since meta-analysis uses various types of data such as academic journals and dissertations, the results may be distorted if the studies analyzed do not represent the entire phenomenon and report the size in certain directions. Therefore, funnel plots and the stability coefficients (fail-safe $\mathrm{N}$ ) should be analyzed to verify the bias of the data.

In general, it is judged that there is no publication bias when the schematics of the funnel plot are symmetrical, and when the stability coefficient is greater than $5 \mathrm{~K}+10$, there is no publication bias. Therefore, the model in this study is judged to have no publication bias (Table 4). 
Table 4. Verification of publication bias (left: German hidden champion firms (Overseas), right: South Korean MMEs (Domestic)).

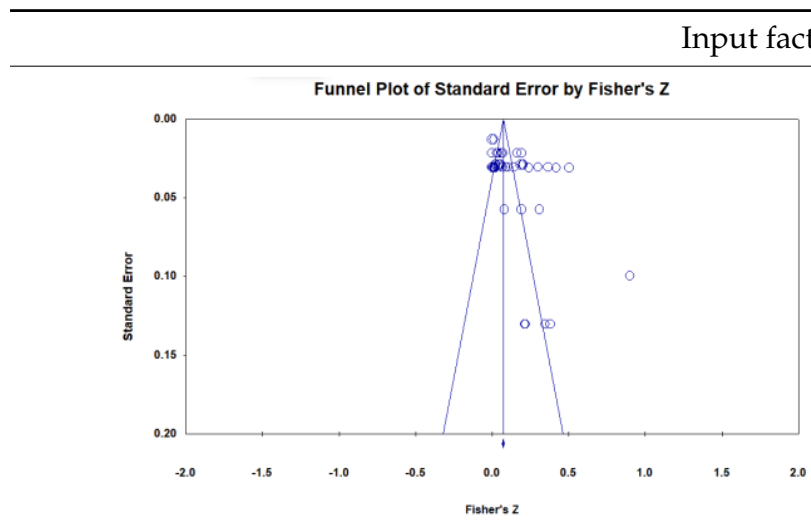

Z-value: $24.971 / p$-value: $0.000 / \alpha: 0.05 / Z$ for $\alpha$ : 1.95/K:75/stability coefficient: 2100

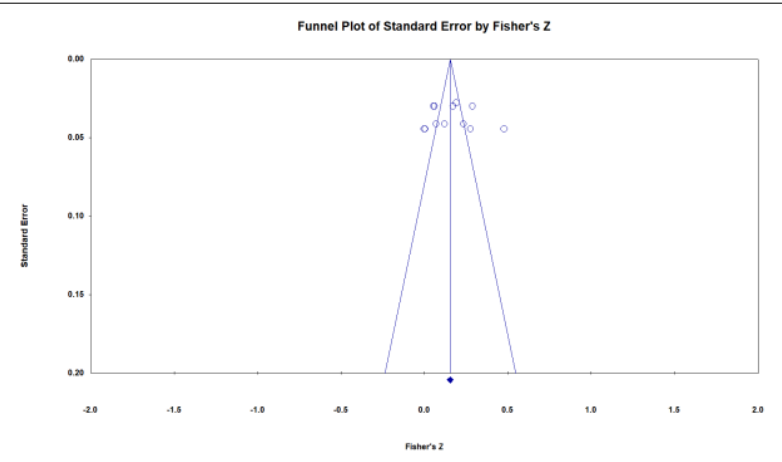

Z-value: $14.317 / p$-value: $0.000 / \alpha: 0.05 / Z$ for $\alpha$ : 1.95/K:12/stability coefficient: 629

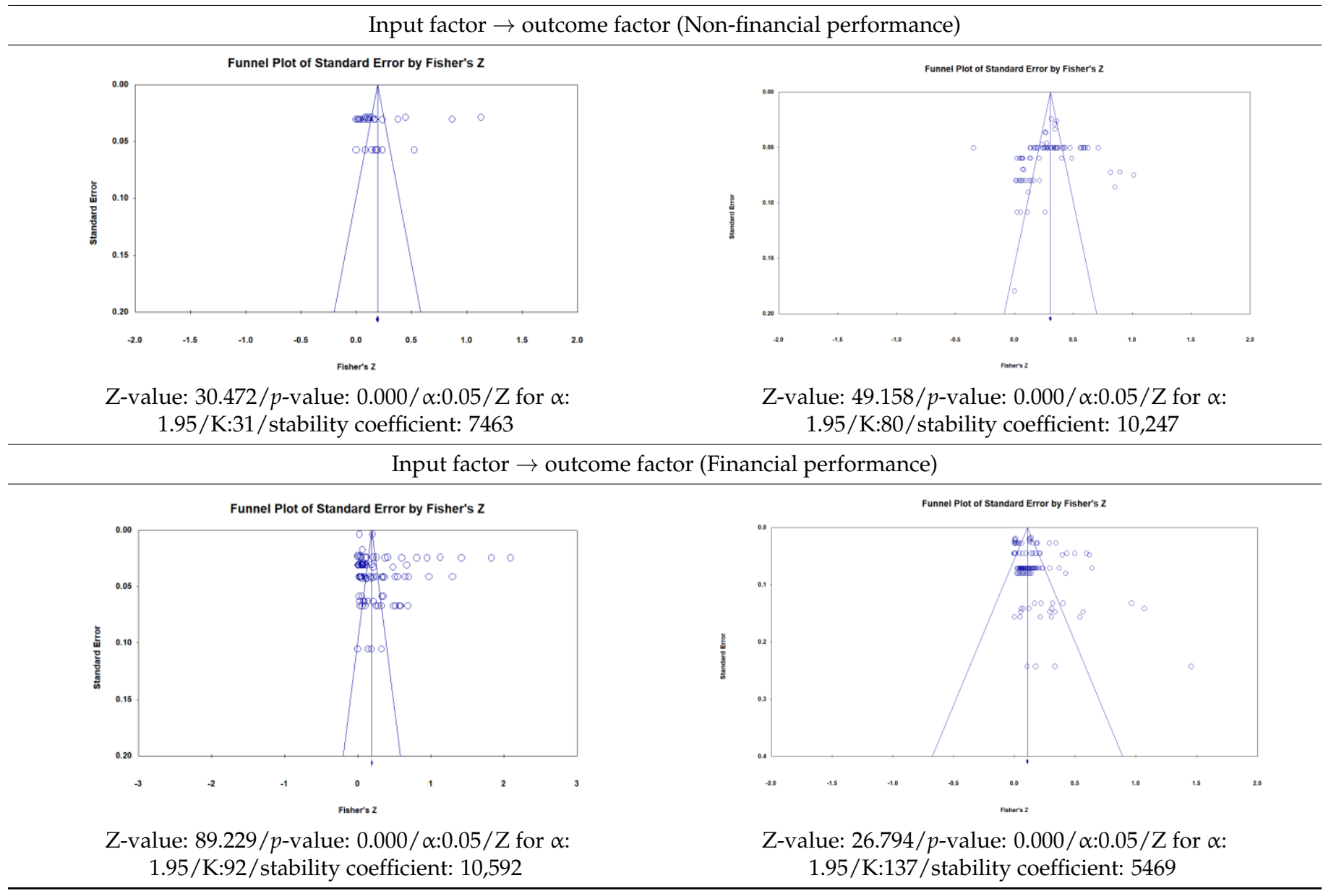

\subsection{Homogeneity Verification}

Homogeneity verification is checking how heterogeneous the effect sizes are. In general, homogeneity is checked with the test statistic $Q$ value and the $\mathrm{I}^{2}$ value. The $\mathrm{Q}$ value was found to be statistically significant $(p=0.000)$. In addition, the $\mathrm{I}^{2}$ value, which is interpreted as a percentage of variability of the effect sizes, was also analyzed to be 75 or higher, confirming heterogeneity between the effect sizes [34] (Table 5). Therefore, the average effect size calculation is reported by adopting a random effect model [31]. 
Table 5. Results of homogeneity verification.

\begin{tabular}{lcccccc}
\hline & Analysis Model & K & ES & $\mathbf{Q}$ & $\boldsymbol{p}$ & $\mathbf{I}^{\mathbf{2}}$ \\
\hline Overseas & Input $\rightarrow$ Inno_Process & 75 & 0.097 & 1016.25 & 0.000 & 92.718 \\
Overseas & Input $\rightarrow$ Non_financial & 31 & 0.163 & 2071.641 & 0.000 & 98.551 \\
Overseas & Input $\rightarrow$ Financial & 92 & 0.086 & $21,444.439$ & 0.000 & 99.575 \\
Domestic & Input $\rightarrow$ Inno_Process & 12 & 0.148 & 136.176 & 0.000 & 91.922 \\
Domestic & Input $\rightarrow$ Non_financial & 80 & 0.287 & 899.129 & 0.000 & 91.214 \\
Domestic & Input $\rightarrow$ Financial & 137 & 0.136 & 1076.179 & 0.000 & 87.363 \\
\hline
\end{tabular}

$\mathrm{K}=$ number of effect sizes, $\mathrm{ES}=$ effect size, $\mathrm{Q}=\mathrm{Q}$ value, $p=$ significance level, $\mathrm{I}^{2}=\%$ of the variability of the effect sizes.

\section{Result}

\subsection{Size of the Effect of Output (Innovation Process + Innovation Outcome)}

Table 6 shows the results of the comparison of the output factors of German hidden champion firms (Overseas) and South Korean MMEs (Domestic). In this table, the results of comparison and analysis were conducted without distinguishing activity factors from outcome factors. As presented earlier, the input factors of overseas studies were different from those of domestic studies, and the sizes of effects were also different. According to Cohen (1988)'s analysis criteria, 0.10 to 0.23 values are interpreted as small effect sizes, 0.24 to 0.36 as medium effect sizes, and 0.37 or larger as large effect sizes [35].

The effect sizes of German hidden champion firms were analyzed, and, according to the results, the top factors (over 0.37) were shown to be closed innovation (0.739) and open innovation (0.437), and the middle factors (over 0.24 ) were shown to be human resources (0.330) and labor productivity (0.305), the CEO's experience (0.303), exports $(0.242)$, and the location in western Germany (0.242). It can be said that innovation activities affect overall innovation performance, and the importance of human resources could be identified. It is judged that, in the case of Germany, since workers are systematically fostered through the apprenticeship system to cultivate manpower for SMEs, these workers can play the role of core resources for the enhancement of competitive power later. In addition, it was identified that the importance of closed innovation was greater than that of open innovation so that the importance of innovation activities inside and outside the firm could be confirmed, and this indicates that internal cooperation needs to precede first, prior to cooperation with external organizations [36].

On the other hand, in the case of South Korean MMEs, the effect sizes were shown to be the largest in the case of size (0.340), followed by innovation orientation (0.323) and innovation capability (0.296). The importance of effect sizes was derived from relatively fewer factors compared to German hidden champions. In addition, it was found that the size and innovation capability of firms affect the innovation performance so that it is judged that firms of at least a certain size can perform based on the stability of funds. In addition, the innovation orientation within the firm was found to have an important effect on performance so that the importance of organizational innovation, which is a non-technical innovation, could be identified. 
Table 6. Comparison of the sizes of the effects of outputs in domestic and overseas literature.

\begin{tabular}{|c|c|c|c|c|c|}
\hline & \multirow{3}{*}{ Input } & \multicolumn{4}{|c|}{$\begin{array}{c}\text { Output } \\
\text { (Innovation Process + Innovation Performance) }\end{array}$} \\
\hline & & \multicolumn{2}{|c|}{ Overseas } & \multicolumn{2}{|c|}{ Domestic } \\
\hline & & $\mathbf{K}$ & ES & $\mathbf{K}$ & ES \\
\hline Firm Position & Size & 13 & $0.225^{* * *}$ & 18 & $0.340^{* * *}$ \\
\hline Firm Position & Age & 16 & $0.140^{* * *}$ & 13 & $0.119 * *$ \\
\hline Firm Position & Location & 12 & $0.242 *$ & 4 & $0.178 *$ \\
\hline Firm Position & Industry & 5 & 0.054 & 16 & $0.076^{* * *}$ \\
\hline Firm Position & Credit & 5 & $0.037 *$ & & \\
\hline Firm Position & Export & 4 & $0.242^{* *}$ & 9 & $0.065 *$ \\
\hline Firm Position & Market share & 3 & 0.070 & & \\
\hline Firm Position & Family firm & 10 & $0.077^{* * *}$ & & \\
\hline Firm Position & Number of employees & 10 & $0.041 *$ & 8 & $0.162 *$ \\
\hline Firm Position & Human Capital & 10 & 0.330 * & & \\
\hline Firm Position & Labor productivity & 4 & $0.305 *$ & & \\
\hline Firm Position & Financial condition & 37 & $0.225^{* * *}$ & 31 & $0.116^{* * *}$ \\
\hline Firm Position & subsidy & 7 & $0.073^{* *}$ & 51 & $0.196^{* * *}$ \\
\hline Firm Position & Education & 2 & 0.025 & & \\
\hline Firm Position & Experience & 9 & $0.303^{* * *}$ & & \\
\hline Innovation Path & Innovation Orientation & 11 & $0.098^{* *}$ & 25 & $0.323^{* * *}$ \\
\hline Innovation Path & Inno_compatency & 8 & $0.127^{* *}$ & 21 & $0.296^{* * *}$ \\
\hline Innovation Path & Open Innovation & 11 & $0.437^{* *}$ & 12 & $0.125 *$ \\
\hline Innovation Path & In house Innovation & 5 & $0.739 *$ & & \\
\hline Innovation Path & R\&D & 16 & 0.209 * & 21 & $0.129^{* * *}$ \\
\hline & $\mathrm{K}$ & & 8 & & 29 \\
\hline & ES & & 10 & & 95 \\
\hline & $\mathrm{Q}$ & & 7.278 & & .563 \\
\hline & $\hat{p}$ & & 00 & & 00 \\
\hline & $\mathrm{I}^{2}$ & & 228 & & 371 \\
\hline
\end{tabular}

\subsection{Comparison of the Sizes of Effects on Innovation Processes}

Table 7 is the results of the analysis of the sizes of the effects of factors affecting the innovation process, which is an activity factor. Whereas the number of $\mathrm{K}$ was found to be 75 in the case of overseas studies, it was found to be 12 in the case of domestic studies, indicating that the studies were relatively insufficient.

Commonly, some of the input factors of firms included 0 in the confidence interval, indicating that they were not statistically significant. Among the significant factors of German hidden champion firms, the factors with large effects were shown to be open innovation (0.716), labor productivity (0.396), CEO experience (0.281), export share $(0.224)$, skilled manpower (0.140), and R\&D expenditure (0.101) in order of precedence.

On the other hand, in the case of Korean MMEs, the proportion of government subsidies (0.175) was found to have a significant effect on innovation activities. 
Table 7. Comparison of the sizes of effects on activity factors (innovation activities) in domestic and overseas literature.

\begin{tabular}{|c|c|c|c|c|c|c|c|c|c|c|c|}
\hline & \multirow{3}{*}{ Input } & \multicolumn{10}{|c|}{ Innovation Process } \\
\hline & & \multicolumn{5}{|c|}{ Overseas } & \multicolumn{5}{|c|}{ Domestic } \\
\hline & & $\mathbf{K}$ & ES & $\begin{array}{c}-95 \% \\
\text { CI }\end{array}$ & $\begin{array}{c}+95 \% \\
\text { CI }\end{array}$ & $p$ & $\mathbf{K}$ & ES & $\begin{array}{c}-95 \% \\
\text { CI }\end{array}$ & $\begin{array}{c}+95 \% \\
\text { CI }\end{array}$ & $p$ \\
\hline Firm Position & Size & 2 & $0.047 * *$ & 0.012 & 0.082 & 0.009 & & & & & \\
\hline Firm Position & Age & 5 & 0.139 & $(0.027)$ & 0.305 & 0.102 & 2 & 0.037 & $(0.013)$ & 0.088 & 0.147 \\
\hline Firm Position & Location & 6 & 0.108 & $(0.006)$ & 0.222 & 0.063 & & & & & \\
\hline Firm Position & Industry & 4 & $0.049^{* * *}$ & 0.024 & 0.073 & 0.000 & 1 & 0.070 & $(0.011)$ & 0.150 & 0.088 \\
\hline Firm Position & Credit & 4 & $0.045^{*}$ & 0.009 & 0.081 & 0.014 & & & & & \\
\hline Firm Position & Export & 2 & $0.224 * *$ & 0.094 & 0.348 & 0.001 & 2 & 0.042 & $(0.011)$ & 0.094 & 0.119 \\
\hline Firm Position & Market share & 2 & 0.000 & $(0.035)$ & 0.035 & 1.000 & & & & & \\
\hline Firm Position & Family firm & 5 & $0.054 *$ & 0.010 & 0.097 & 0.015 & & & & & \\
\hline Firm Position & Number of employees & 6 & 0.025 & $(0.007)$ & 0.057 & 0.129 & & & & & \\
\hline Firm Position & Human Capital & 5 & $0.140 *$ & 0.025 & 0.255 & 0.017 & & & & & \\
\hline Firm Position & Labor productivity & 1 & $0.396^{* * *}$ & 0.343 & 0.446 & 0.000 & & & & & \\
\hline Firm Position & Financial condition & 8 & $0.040^{* * *}$ & 0.020 & 0.061 & 0.000 & 2 & $0.042 * * *$ & $(0.011)$ & 0.094 & 0.000 \\
\hline Firm Position & subsidy & 7 & $0.072 * *$ & 0.020 & 0.124 & 0.007 & 4 & $0.175 * *$ & 0.108 & 0.241 & 0.003 \\
\hline Firm Position & Education & & & & & & & & & & \\
\hline Firm Position & Experience & 4 & $0.281^{* * *}$ & 0.160 & 0.394 & 0.000 & & & & & \\
\hline Innovation Path & Innovation Orientation & & & & & & & & & & \\
\hline Innovation Path & Inno_compatency & 3 & 0.092 & $(0.046)$ & 0.225 & 0.191 & 1 & 0.120 & 0.040 & 0.199 & 0.088 \\
\hline Innovation Path & Open Innovation & 1 & $0.716^{* * *}$ & 0.607 & 0.798 & 0.000 & & & & & \\
\hline Innovation Path & In house Innovation & & & & & & & & & & \\
\hline \multirow[t]{2}{*}{ Innovation Path } & R\&D & 10 & $0.101 * *$ & 0.043 & 0.157 & 0.001 & & & & & \\
\hline & Total & 75 & $0.070 * * *$ & 0.060 & 0.080 & 0.000 & 12 & $0.082 * * *$ & 0.055 & 0.110 & 0.000 \\
\hline
\end{tabular}

${ }^{*} p<0.05,{ }^{* *} p<0.01,{ }^{* * *} p<0.001, \mathrm{~K}=$ number of effect sizes, $\mathrm{ES}=$ effect size, $\mathrm{CI}=$ confidence interval $p=$ significance level.

\subsection{Comparison of the Sizes of Effects on Non-Financial Performance}

Table 8 shows the results of the analysis of the sizes of the effects of factors affecting non-financial performance among outcomes. Whereas the number of $\mathrm{K}$ was found to be 31 in the case of overseas studies, it was found to be 78 in the case of domestic studies, indicating that more diverse studies were conducted in South Korea.

Among the results of German hidden champion firms, the factors with the large statistically significant effects were R\&D expenditure (0.616), export share (0.448), innovation capability (0.203), and financial characteristics (0.141) in order of precedence.

On the other hand, in the case of Korean MMEs, the effect of innovation capability was the largest (0.373), followed by innovation orientation within the firm (0.323), government subsidy (0.303), the level of manpower (0.266), and financial characteristics (0.137) in order of precedence. 
Table 8. Comparison of the sizes of effects on outcome factors (non-financial performance) in domestic and overseas literature.

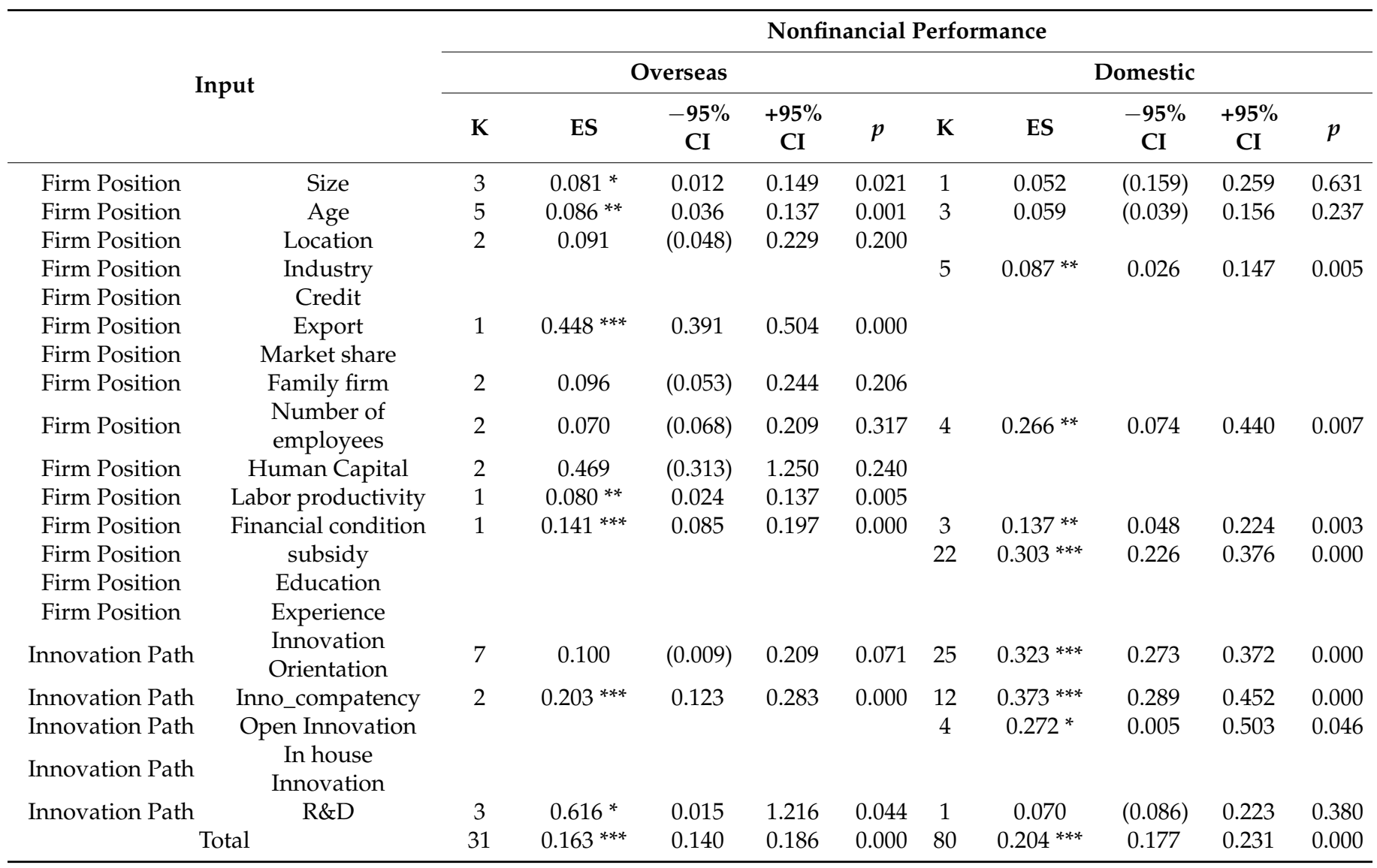

$* p<0.05, * * p<0.01, * * * p<0.001, \mathrm{~K}=$ number of effect sizes, $\mathrm{ES}=$ effect size, $\mathrm{CI}=$ confidence interval $p=$ significance level.

\subsection{Comparison of the Sizes of Effects on Financial Performance}

Table 9 shows the results of the analysis of the sizes of the effects of factors affecting financial performance among outcomes. Whereas the number of $\mathrm{K}$ was found to be 92 in the case of overseas studies, it was found to be 137 in the case of domestic studies. In the results of German hidden champion firms, the factors with the large statistically significant effect sizes were shown to be introverted innovation (0.739), firm size (0.319), CEO's experience (0.312), financial characteristics (0.275), market share (0.213), history (0.181), R\&D expenditure (0.164), and industrial characteristics (0.141) in order of precedence. On the other hand, in the case of South Korean MMEs, those were shown to be firm size (0.355), innovation capability (0.198), location of the firm (0.178), history (0.160), R\&D expenditure (0.132), and export share (0.109) in order of precedence. 
Table 9. Comparison of the sizes of effects on outcome factors (financial performance) in domestic and overseas literature.

\begin{tabular}{|c|c|c|c|c|c|c|c|c|c|c|c|}
\hline & \multirow{3}{*}{ Input } & \multicolumn{10}{|c|}{ Financial Performance } \\
\hline & & \multicolumn{5}{|c|}{ Overseas } & \multicolumn{5}{|c|}{ Domestic } \\
\hline & & $\mathbf{K}$ & ES & $-95 \% \mathrm{CI}$ & $+95 \% \mathrm{CI}$ & $p$ & $\mathbf{K}$ & ES & $\begin{array}{c}-95 \% \\
\text { CI }\end{array}$ & $\begin{array}{c}+95 \% \\
\text { CI }\end{array}$ & $p$ \\
\hline Firm Position & Size & 8 & $0.319^{* * *}$ & 0.151 & 0.470 & 0.000 & 17 & $0.355^{* * *}$ & 0.242 & 0.459 & 0.000 \\
\hline Firm Position & Age & 6 & $0.181 * * *$ & 0.079 & 0.282 & 0.000 & 8 & $0.160 * *$ & 0.061 & 0.255 & 0.002 \\
\hline Firm Position & Location & 4 & 0.519 & $(0.003)$ & 1.040 & 0.051 & 4 & $0.178 *$ & 0.027 & 0.321 & 0.021 \\
\hline Firm Position & Industry & 1 & $0.141 *$ & 0.017 & 0.264 & 0.025 & 10 & $0.075^{* * *}$ & 0.039 & 0.110 & 0.000 \\
\hline Firm Position & Credit & 1 & 0.001 & $(0.060)$ & 0.062 & 0.974 & & & & & \\
\hline Firm Position & Export & 1 & 0.059 & $(0.002)$ & 0.120 & 0.057 & 7 & $0.109 *$ & 0.011 & 0.205 & 0.029 \\
\hline Firm Position & Market share & 1 & $0.213^{* * *}$ & 0.149 & 0.278 & 0.000 & & & & & \\
\hline Firm Position & Family firm & 3 & $0.116^{* *}$ & 0.039 & 0.191 & 0.003 & & & & & \\
\hline Firm Position & $\begin{array}{l}\text { Number of } \\
\text { employees }\end{array}$ & 2 & 0.067 & $(0.031)$ & 0.164 & 0.180 & 4 & 0.050 & $(0.028)$ & 0.128 & 0.210 \\
\hline Firm Position & Human Capital & 3 & 0.555 & $(0.340)$ & 1.450 & 0.224 & & & & & \\
\hline Firm Position & Labor productivity & 2 & 0.361 & $(0.249)$ & 0.972 & 0.246 & & & & & \\
\hline Firm Position & Financial condition & 28 & $0.275^{* * *}$ & 0.164 & 0.379 & 0.000 & 26 & $0.090^{* * *}$ & 0.043 & 0.136 & 0.000 \\
\hline Firm Position & subsidy & & & & & & 25 & $0.085^{* * *}$ & 0.053 & 0.117 & 0.000 \\
\hline Firm Position & Education & 2 & 0.025 & $(0.007)$ & 0.057 & 0.122 & & & & & \\
\hline Firm Position & Experience & 5 & $0.312^{* *}$ & 0.102 & 0.523 & 0.004 & & & & & \\
\hline Innovation Path & $\begin{array}{l}\text { Innovation } \\
\text { Orientation }\end{array}$ & 4 & $0.074 *$ & 0.012 & 0.137 & 0.019 & & & & & \\
\hline Innovation Path & Inno_compatency & 3 & 0.110 & $(0.009)$ & 0.230 & 0.070 & 8 & $0.198 *$ & 0.035 & 0.351 & 0.018 \\
\hline Innovation Path & Open Innovation & 10 & 0.391 & $(0.016)$ & 0.799 & 0.060 & 8 & 0.049 & $(0.003)$ & 0.099 & 0.062 \\
\hline Innovation Path & In house Innovation & 5 & $0.739 *$ & 0.013 & 1.465 & 0.046 & & & & & \\
\hline \multirow{2}{*}{ Innovation Path } & $R \& D$ & 3 & $0.164 *$ & 0.007 & 0.321 & 0.040 & 20 & $0.132 * * *$ & 0.090 & 0.174 & 0.000 \\
\hline & Total & 92 & $0.086^{* * *}$ & 0.069 & 0.103 & 0.000 & 137 & $0.095^{* * *}$ & 0.079 & 0.111 & 0.000 \\
\hline
\end{tabular}

$* p<0.05,{ }^{* *} p<0.01,{ }^{* * *} p<0.001, \mathrm{~K}=$ number of effect sizes, $\mathrm{ES}=$ effect size, $\mathrm{CI}=$ confidence interval $p=$ significance level.

\section{Conclusions}

This study conducted meta-analyses with previous studies on German hidden champions and South Korean MMEs. Since Germany has similar industrial and economic structures to those of South Korea, it has been continuously argued that German hidden champion firms should be benchmarked to develop the capabilities of South Korean MMEs. Therefore, this study compared and analyzed factors affecting performance with studies on similar firm groups in the two countries. In particular, the differences were compared from the viewpoint of position, path, and process, which are major factors of dynamic capabilities, and the logic model was modified and applied to the process up to performance creation.

According to the results of the analysis, German hidden champion firms and domestic middle market enterprises had similar firm size and characteristics but had different detailed factors that affect performance. This is considered attributable to differences in the management environments and management philosophies of firms in the individual countries. In particular, the variable entrepreneurial characteristics were used as important variables in studies in Germany, but it was not used in Korean studies. The foregoing is judged to have reflected the fact that studies on entrepreneurial characteristics perceived that entrepreneurial characteristics are important in start-up firms in their early stage and SMEs but the characteristics of managers who pursue efficiency are important in mature firm groups such as middle market enterprises. However, considering the reality that South Korean middle market enterprises are sunk in growth stagnation, it is necessary to benchmark overseas cases to cultivate the entrepreneurial spirit. We need to understand that hidden champions internally establish their corporate identity and that the values of the founder or entrepreneur who runs the company are reflected in the brand [12].

Although the internal and external environmental characteristics of the firms in the two countries are different, factors that affect their performance were analyzed concretely because they should be applied according to the South Korean policy environment (Table 10). 
Table 10. Comprehensive growth engines of middle market enterprises.

\begin{tabular}{|c|c|c|}
\hline & Overseas & Domestic \\
\hline Firm Position & $\begin{array}{c}\text { Firm size } \\
\text { History } \\
\text { Industrial characteristics } \\
\text { Proportion of exports } \\
\text { Market share } \\
\text { Family firm }\end{array}$ & $\begin{array}{c}\text { Firm size } \\
\text { History } \\
\text { Location } \\
\text { Proportion of exports } \\
\text { Market share }\end{array}$ \\
\hline Firm Position & $\begin{array}{l}\text { Skilled manpower } \\
\text { Labor productivity } \\
\text { Financial position }\end{array}$ & $\begin{array}{l}\text { Level of manpower } \\
\text { Financial position } \\
\text { Government subsidy }\end{array}$ \\
\hline Firm Position & CEO's experience & \\
\hline Innovation Path & $\begin{array}{l}\text { Open innovation } \\
\text { Introverted innovation } \\
\text { Proportion of } R \& D\end{array}$ & $\begin{array}{c}\text { Innovation orientation } \\
\text { Innovation capability } \\
\text { Open innovation } \\
\text { Proportion of R\&D }\end{array}$ \\
\hline
\end{tabular}

The factors that commonly affect the performance of German hidden champion firms and that of South Korean MMEs were found to be firm size, history, the proportion of exports, market share, financial position, and the proportion of R\&D. Although not derived from Korean studies, when the factors that create the performance of hidden champion firms were analyzed, the proportion of skilled manpower and labor productivity were found to have important effects, indicating that competitive power can be secured by benchmarking the management and training of human resources. The trust and sense of the companionship of human resources will become a source that can induce the best customer service and will consequently create a virtuous cycle of firm growth [11]. In addition, given the results of many previous studies indicating that the expansion of human resources is important for the performance of technological innovation of SMEs, constructing a system to secure, cultivate, and maintain excellent technical manpower will be necessary for the R\&D-based growth of middle market enterprises.

Germany tends to focus on entrepreneurial spirit and vertical market expansion. German firms are characterized by focusing on providing customized value packages that can best combine their strengths in order to secure niche markets but to maintain technology-oriented niche markets rather than price- and volume-oriented markets [11]. This indicates that since the firms are small but highly flexible, they focus on making good use of their internal resources and capabilities. Additionally, these results support the results of previous studies indicating that internal technical cooperation and processes are more important than external organizations' cooperation for SMEs' technological innovation [37]. These results suggest that MMEs in Korea, which are highly dependent on large corporations, need to establish strategies to secure competitiveness in the market based on their own specialized innovation capabilities.

In addition, although government subsidies were found to be an important factor for domestic firms, the foregoing suggests that in order to achieve the growth and independence of firms from a long-term perspective, they should focus on attracting private investments rather than government investment support.

This study not only provides academic and policy implications but also will be a useful reference for future studies in that it has attempted a meta-analysis of German hidden champion firms and domestic middle market enterprises for the first time. In particular, it was identified from the results of this study that in the case of German hidden champion firms, the characteristics of innovation networks that enable active industryuniversity joint research are activated and that regional and specialized vocational training, technology development, and employment can be systematically linked and consequently lead to the creation of performance. Additionally, in the case of South Korea, various policies are being implemented to foster middle market enterprises, but in order not 
to end with short-term support, middle market enterprises should focus on reducing their dependence on large firms and lay the groundwork for self-reliance in the long term. In order to reduce social polarization and stabilize employment, it is necessary to reduce wage gaps for professional workers and develop specialized manpower training programs and career paths in connection with R\&D investment strategies. In order for the apprenticeship program to train German master craftsmen (meisters) to take root in Korean society, the recognition that workers with the same value should be paid the same wages without discrimination based on gender, age, or status needs to be established in advance [11]. In addition, as digitalization is accelerating due to the recent COVID-19 pandemic, it is necessary to closely examine the German Mittelstand 4.0 policy to find a balance between the digitization of production and work processes, employment stability, and the improvement of labor productivity.

Author Contributions: Conceptualization, M.K., S.L. and Y.-w.S.; data curation, M.K. and Y.-w.S.; formal analysis, M.K., S.L. and Y.-w.S.; methodology, M.K.; project administration, M.K.; validation S.L. and Y.-w.S.; writing—original draft preparation, M.K.; writing—review and editing, M.K., S.L., and Y.-w.S. All authors have read and agreed to the published version of the manuscript.

Funding: This work was supported by the Ministry of Education of the Republic of Korea and the National Research Foundation of Korea (NRF-S201909S00048). This work was supported by a research grant from Seoul Women's University (2021-0450).

Institutional Review Board Statement: Not applicable.

Informed Consent Statement: Not applicable.

Data Availability Statement: Not applicable.

Conflicts of Interest: The authors declare no conflict of interest.

Appendix A

Table A1. Operational Definition of Variable.

\begin{tabular}{|c|c|c|}
\hline \multirow{2}{*}{$\begin{array}{l}\text { Variable Name } \\
\text { Firm Position }\end{array}$} & \multicolumn{2}{|r|}{ Operational Definition } \\
\hline & Size & Firm size based on sales \\
\hline Firm Position & Age & Firm history \\
\hline Firm Position & Location & (Overseas, western Germany, Domestic) metropolitan area \\
\hline Firm Position & Industry & $\begin{array}{c}\text { Industrial characteristics, such as the intensity of industrial competition, industrial rate of } \\
\text { return, or growth rate }\end{array}$ \\
\hline Firm Position & Credit & The creditworthiness of the firm \\
\hline Firm Position & Export & Exports/Sales Ratio \\
\hline Firm Position & Market share & Market share \\
\hline Firm Position & Family firm & Whether the firm is a family firm \\
\hline Firm Position & Number of employees & Number of human resources \\
\hline Firm Position & Human Capital & Number of skilled workers \\
\hline Firm Position & Labor productivity & Labor productivity of workers \\
\hline Firm Position & Financial condition & The financial position of the firm (sales, debt ratio, liquidity) \\
\hline Firm Position & subsidy & Government subsidy/sales \\
\hline Firm Position & Education & Education level of CEO \\
\hline Firm Position & Experience & CEO's experience in related fields \\
\hline Innovation Path & Innovation Orientation & Innovation orientation within the firm (efforts for innovation, such as education and training) \\
\hline Innovation Path & Inno_compatency & $\begin{array}{c}\text { R\&D department arrangement, number of patents and intellectual property rights, new } \\
\text { product development capability }\end{array}$ \\
\hline Innovation Path & Open Innovation & Cooperation activities with organizations outside the firm \\
\hline Innovation Path & In house Innovation & Innovation activities within the firm \\
\hline Innovation Path & $\mathrm{R} \& \mathrm{D}$ & Financial investment in innovation activities such as R\&D investment and R\&D intensity \\
\hline
\end{tabular}




\section{Appendix B}

Table A2. List of Studies Used in the Analysis.

\begin{tabular}{|c|c|c|c|c|}
\hline NO & Author & Type & Input & Output \\
\hline 1 & $\begin{array}{c}\text { Audretsch, D.B. \& Elston, J A } \\
\text { (2006) [38] }\end{array}$ & IP & $\begin{array}{c}\text { Size } \\
\text { Age } \\
\text { Financial condition }\end{array}$ & Financial Performance \\
\hline 2 & $\begin{array}{l}\text { Classen, N., Carree, M., Gils, } \\
\text { A.V. \& Peters, B. (2014) [39] }\end{array}$ & IAP & $\begin{array}{c}\text { Size } \\
\text { Age } \\
\text { Location } \\
\text { Industry } \\
\text { Export } \\
\text { Human capital } \\
\text { Market share } \\
\text { Family firm } \\
\text { Inno_compatency }\end{array}$ & $\begin{array}{c}\text { Inno_Process / } \\
\text { Non_Financial/ } \\
\text { Financial Performance }\end{array}$ \\
\hline 3 & $\begin{array}{c}\text { Rant, M., \& Černe, S. (2017) } \\
{[40]}\end{array}$ & IP & $\begin{array}{l}\text { Inno_compatency } \\
\text { Innovation orientation }\end{array}$ & Financial Performance \\
\hline 4 & Gruenwald, R. K. (2016) [41] & IP & $\begin{array}{c}\text { Size } \\
\text { Financial condition } \\
\text { R\&D }\end{array}$ & Financial Performance \\
\hline 5 & Bartz and Winkler (2016) [42] & IP & $\begin{array}{c}\text { Age } \\
\text { Innovation orientation }\end{array}$ & Financial Performance \\
\hline 6 & Rammer et al. (2009) [43] & IP & $\begin{array}{c}\text { Size } \\
\text { Age } \\
\text { In_house_innovation } \\
\text { Open Innovation } \\
\text { Innovation orientation } \\
\text { Subsidy }\end{array}$ & Non_Financial \\
\hline 7 & Sch“"afer et al. (2017) [44] & IA & $\begin{array}{c}\text { Location } \\
\text { Family firm } \\
\text { Human capital } \\
\text { R\&D } \\
\text { Financial condition } \\
\text { Subsidy }\end{array}$ & Inno_Process \\
\hline 8 & $\begin{array}{c}\text { Rammer, C. \& Schmiele, A. } \\
\text { (2008) [45] }\end{array}$ & IP & $\begin{array}{c}\text { Size } \\
\text { Age } \\
\text { Location } \\
\text { Labor productivity } \\
\text { Human capital } \\
\text { Open Innovation } \\
\text { In house Innovation } \\
\text { R\&D }\end{array}$ & $\begin{array}{l}\text { Non_Financial/ } \\
\text { Financial Performance }\end{array}$ \\
\hline 9 & $\begin{array}{c}\text { Almus, M. \& Czarnitzki, D. } \\
\text { (2003) [46] }\end{array}$ & IP & $\begin{array}{c}\text { Age } \\
\text { Market share } \\
\text { Export } \\
\text { Financial condition } \\
\text { Number of employees } \\
\text { Inno_compatency } \\
\text { Open Innovation }\end{array}$ & Financial Performance \\
\hline 10 & Harms, R.(2009) [47] & IP & $\begin{array}{c}\text { Size } \\
\text { Age } \\
\text { Experience } \\
\text { R\&D } \\
\text { Open Innovation }\end{array}$ & Financial Performance \\
\hline
\end{tabular}


Table A2. Cont.

\begin{tabular}{|c|c|c|c|c|}
\hline NO & Author & Type & Input & Output \\
\hline 11 & $\begin{array}{l}\text { Hertel, M. \& Menrad, K. } \\
\text { (2016) [48] }\end{array}$ & IA & Open innovation & Inno_Process \\
\hline 12 & $\begin{array}{l}\text { Müller and Zimmermann } \\
\text { (2009) [49] }\end{array}$ & IA & $\begin{array}{c}\text { Age } \\
\text { Financial condition }\end{array}$ & Inno_Process \\
\hline 13 & $\begin{array}{l}\text { Czarnitzki, D. \& Dlanote } \\
\text { (2015) [50] }\end{array}$ & IA & $\begin{array}{c}\text { Age } \\
\text { Export } \\
\text { Location } \\
\text { Credit } \\
\text { Number of employees } \\
\text { Financial condition } \\
\text { Labor productivity } \\
\text { Subsidy }\end{array}$ & Inno_Process \\
\hline 14 & $\begin{array}{l}\text { Block, J. h. \& Wagner, M. } \\
\text { (2010) [51] }\end{array}$ & IP & $\begin{array}{l}\text { Education } \\
\text { Experience }\end{array}$ & Financial Performance \\
\hline 15 & $\begin{array}{c}\text { Andries, P. \& Czarnitzki, D. } \\
\text { (2014) [52] }\end{array}$ & IP & $\begin{array}{c}\text { Age } \\
\text { Number of employees } \\
\text { Inno_compatency } \\
\text { R\&D }\end{array}$ & $\begin{array}{l}\text { Non_Financial } \\
\text { Performance }\end{array}$ \\
\hline 16 & $\begin{array}{l}\text { Harms, R., Wagner, M. \& } \\
\text { Glauner, W.(2010) [53] }\end{array}$ & IA & Experience & Inno_Process \\
\hline 17 & Calabrò et al.(2017) [54] & IP & $\begin{array}{c}\text { Size } \\
\text { Age } \\
\text { Industry } \\
\text { Family firm }\end{array}$ & Financial Performance \\
\hline 18 & $\begin{array}{l}\text { Steeger \& Hoffmann (2016) } \\
\text { [55] }\end{array}$ & IP & $\begin{array}{c}\text { Size } \\
\text { Age } \\
\text { Export } \\
\text { R\&D } \\
\text { Labor productivity } \\
\text { Financial condition } \\
\text { Innovation Orientation }\end{array}$ & $\begin{array}{l}\text { Non_Financial } \\
\text { Performance }\end{array}$ \\
\hline 19 & $\begin{array}{c}\text { Ahn, Seungku et al. (2017) } \\
\text { [56] }\end{array}$ & IA & $\begin{array}{c}\text { Subsidy } \\
\text { Inno_compatency } \\
\text { Industry }\end{array}$ & Inno_Process \\
\hline 20 & Oh, Chung Hyun (2014) [57] & IA & $\begin{array}{c}\text { Subsidy } \\
\text { Size } \\
\text { Inno_compatency }\end{array}$ & Inno_Process \\
\hline 21 & $\begin{array}{c}\text { Jeon, Kwang-Hak et al. } \\
\text { (2018) [58] }\end{array}$ & IAP & $\begin{array}{c}\text { R\&D } \\
\text { Inno_compatency } \\
\text { Subsidy } \\
\text { Financial condition } \\
\text { Size }\end{array}$ & $\begin{array}{c}\text { Inno_Process / } \\
\text { Financial Performance }\end{array}$ \\
\hline 22 & Jeon, Joong-yang (2018) [59] & IAP & Open Innovation & $\begin{array}{c}\text { Inno_Process/ } \\
\text { Financial Performance }\end{array}$ \\
\hline 23 & Jung, Gap Jin (2015) [60] & IA & $\begin{array}{l}\text { Innovation Orientation } \\
\text { Inno_compatency }\end{array}$ & Inno_Process \\
\hline 24 & Jung, Jun-ho et al. (2016) [61] & IA & $\begin{array}{c}\text { Subsidy } \\
\text { Financial condition } \\
\text { Export } \\
\text { Age }\end{array}$ & Inno_Process \\
\hline 25 & Jung, Jun-ho (2017) [62] & IP & Subsidy & $\begin{array}{c}\text { Non_Financial } \\
\text { Performance }\end{array}$ \\
\hline
\end{tabular}


Table A2. Cont.

\begin{tabular}{|c|c|c|c|c|}
\hline NO & Author & Type & Input & Output \\
\hline 26 & $\begin{array}{l}\text { Hwang, Seong-wook (2017) } \\
\text { [63] }\end{array}$ & IP & $\begin{array}{c}\text { Age } \\
\text { Size } \\
\text { Open Innovation } \\
\text { R\&D } \\
\text { Financial condition }\end{array}$ & Financial Performance \\
\hline 27 & Kim, Do-Eui et al. (2020) [64] & IP & $\begin{array}{c}\text { Number of employees } \\
\text { Subsidy }\end{array}$ & $\begin{array}{l}\text { Non_Financial } \\
\text { Performance }\end{array}$ \\
\hline 28 & Kim, Do-Eui (2021) [65] & IP & $\begin{array}{l}\text { Number of employees } \\
\text { Industry }\end{array}$ & $\begin{array}{l}\text { Non_Financial } \\
\text { Performance }\end{array}$ \\
\hline 29 & $\begin{array}{l}\text { Kim, Jungho \& Kim, Minseo } \\
\text { (2014) [20] }\end{array}$ & IP & $\begin{array}{c}\text { Financial condition } \\
\text { Size } \\
\text { Age } \\
\text { R\&D } \\
\text { Export } \\
\text { Industry }\end{array}$ & Financial Performance \\
\hline 30 & Min, Yong-ki et al. (2021) [66] & IAP & Subsidy & $\begin{array}{c}\text { Inno_Process/ } \\
\text { Non_Financial } \\
\text { Performance }\end{array}$ \\
\hline 31 & $\begin{array}{l}\text { Oh, Han-seok \& Choi, } \\
\text { Gyung-hyun (2020) [67] }\end{array}$ & IP & $\begin{array}{l}\text { Subsidy } \\
\text { Size } \\
\text { R\&D } \\
\text { Export }\end{array}$ & Financial Performance \\
\hline 32 & $\begin{array}{l}\text { Woo, Ki Hoon et al. (2016) } \\
\text { [68] }\end{array}$ & IP & $\begin{array}{l}\text { Number of employees } \\
\text { Inno_compatency }\end{array}$ & Financial Performance \\
\hline 33 & Lee, Byung-yoon (2014) [69] & IA & $\begin{array}{l}\text { Open Innovation } \\
\text { Size }\end{array}$ & Inno_Process \\
\hline 34 & Lee, Jong-ho et al. (2021) [70] & IP & Subsidy & $\begin{array}{l}\text { Non_Financial } \\
\text { Performance }\end{array}$ \\
\hline 35 & $\begin{array}{c}\text { Hyun, Yong-soo et al. (2013) } \\
{[71]}\end{array}$ & IP & $\begin{array}{c}\text { Number of employees } \\
\text { Age } \\
\text { Financial condition } \\
\text { R\&D } \\
\text { Open Innovation }\end{array}$ & Financial Performance \\
\hline 36 & $\begin{array}{c}\text { Hong, Woon Sun \& Kim, Hee } \\
\text { Jae (2018) [72] }\end{array}$ & IP & R\&D & $\begin{array}{l}\text { Non_Financial } \\
\text { Performance }\end{array}$ \\
\hline
\end{tabular}

Type I is input, $\mathrm{A}$ is activities, $\mathrm{P}$ is performance.

\section{References}

1. Rammer, C.; Spielkamp, A. The Distinct Features of Hidden Champions in Germany: A Dynamic Capabilities View; ZEW-LeibnizZentrum für Europäische Wirtschaftsforschung: Mannheim, Germany, 2019.

2. Sawng, Y.; Shin, J.; Kim, M. A Reconsideration of Innovation Failure: Evidence from the Korea Innovation Survey. J. Sci. Ind. Res. 2019, 78, 822-826.

3. Dahlke, J.; Bogner, K.; Becker, M.; Schlaile, M.P.; Pyka, A. Crisis-driven innovation and fundamental human needs: A typological framework of rapid-response COVID-19 innovations. Technol. Forecast. Soc. Chang. 2021, 169, 120799. [CrossRef]

4. Kraus, S.; Clauss, T.; Breier, M.; Gast, J.; Zardini, A.; Tiberius, V. The economics of COVID-19: Initial empirical evidence on how family firms in five European countries cope with the corona crisis. Int. J. Entrep. Behav. Res. 2020, 26, 1067-1092. [CrossRef]

5. Wang, Y.; Hong, A.; Lib, X.; Gao, J. Marketing innovations during a global crisis: A study of China firms' response to COVID-19. J. Bus. Res. 2020, 116, 214-220. [CrossRef] [PubMed]

6. Biron, M.; De Cieri, H.; Fulmer, I.; Lin, C.V.; Mayrhofer, W.; Nyfoudi, M.; Sanders, K.; Shipton, H.; Min, J.; Sun, J. Structuring for innovative responses to human resource challenges: A skunk works approach. Hum. Resour. Manag. Rev. 2020, 31, 100768. [CrossRef]

7. Juergensen, J.; Guimón, J.; Narula, R. European SMEs amidst the COVID-19 crisis: Assessing impact and policy responses. J. Ind. Bus. Econ. 2020, 47, 499-510. [CrossRef] 
8. Cankurtaran, P.; Beverland, M.B. Using design thinking to respond to crises: B2B lessons from the 2020 COVID-19 pandemic. Ind. Mark. Manag. 2020, 88, 255-260. [CrossRef]

9. Kim, M.; Park, H.; Sawng, Y.W.; Park, S.Y. Bridging the gap in the technology commercialization process: Using a three-stage technology-product-market model. Sustainbility 2019, 11, 6267. [CrossRef]

10. Jin, S.H.; Choi, S.O. The Effect of Innovation Capability on Business Performance: A Focus on IT and Business Service Companies. Sustainability 2019, 11, 5246. [CrossRef]

11. Kim, I.-S. A Study on the Business Ecosystem of German SMEs and its Implications for Korean SMEs: Focusing on the Hidden Champion Enterprises in Germany. Koreanische Z. Wirtsch. 2014, 32, $69-95$.

12. Han, I. Overseas Training Results Report_German SME Competitiveness Analysis and SME Growth Ladder Construction Method Research; Ministry of SMEs and Startups: Sejong-si, Korea, 2019.

13. Cho, Y. The search for a new growth system and Growth engine for small and medium-sized enterprises. Future Growth Res. 2019, $5,347$.

14. Sung, M.-J. Corporate Polarization in the Post-Corona Era; Science and Technology Policy Institute: Sejong-si, Korea, 2021.

15. Simon, H. Hidden Champions: Speerspitze der deutschen Wirtschaft. J. Bus. Eco. 1990, 60, 875-890.

16. Simon, H. Hidden Champions of the 21st Century: Success Strategies of Unknown World Market Leaders; Springer: London, UK, 2009.

17. Ko, S.J.; Kim, K.S. Study on the Characteristics of R \& D Investment Pattern for the Middle Size Companies. J. Korea Technol. Innov. Soc. 2009, 12, 525-544.

18. Kang, S.; Park, S. A Relationship between Innovation Capability and Performance: Differences in Firm Development Stages. Asia-Pacific J. Bus. Ventur. Entrep. 2018, 13, 91-100. [CrossRef]

19. Lee, Y.-J.; Kwon, K.-H. Let's Raise a Real Unicorn! STEPI Insight, Science and Technology Policy Institute: Sejong-si, Korea, 2020.

20. Kim, J.; Kim, M. Effects of Innovation and Export on the Performance of Medium-sized Firms: The Moderating Role of Corporate Type. Korean Manag. Rev. 2014, 43, 1787-1812.

21. Voeth, M.; Herbst, U.; Barisch, S. Hidden Champion Region Stuttgart_Ergebnisse einer Empirischen Untersuchung; Hohenheimer Arbeits- und Projektberichte zum Marketin: Hohenheim, Germany, 2007.

22. Yu, H.; Chen, Y. Factors Underlying Hidden Champions in China: Case Study. Master's Thesis, University Halmstad, Halmstad, Sewden, May 2009.

23. Teece, D.J.; Pisano, G.; Shuen, A. Dynamic Capabilities and Strategic Management. Strateg. Manag. J. 1997, 18, 509-533. [CrossRef]

24. Cohen, W.M.; Levintbal, D.A. Absorptive Capacity: A New Perspective on Learning and Innovation. Adm. Sci. Q. 1990, 35, 128-152. [CrossRef]

25. Simon, H. Hidden Champions: Aufbruch Nach Globalia; Campus Verlag GmbH: Frankfurt, Germany, 2012.

26. Audretsch, D.B.; Lehmann, E.E.; Schenkenhofer, J. Internationalization strategies of hidden champions: Lessons from Germany. Multinatl. Bus. Rev. 2018, 26, 2-24. [CrossRef]

27. Kirner, E. Are Knowledge Angels the Secret behind the Success of Hidden Champions and Hidden Innovators? EvoREG Research Note: Basel, Switzerland, 2011.

28. Venohr, B.; Strasse, B.; Berlin, D.; Meyer, K.E. The German Miracle Keeps Running: How Germany 's Hidden Champions Stay Ahead in the Global Economy; Institute of Management, Berlin School of Economics: Berlin, Germany, 2007; pp. 1-35.

29. Seong-dong, H. Easy-to-Understand Meta-Analysis; Hakjisa: Seoul, Korea, 2014.

30. Seong-sam, O. Theory and Practice of Meta-Analysis; Konkuk University Press: Seoul, Korea, 2002.

31. Borenstein, M.; Hedges, L.V.; Higgins, J.P.T.; Rothstein, H.R. Introduction to Meta-Analysis; John Wiley \& Sons, Ltd.: Chichester, UK, 2009.

32. Chung, B.; Hyun, B. Meta-Analysis on Factors Influencing Technology Transfer Performance. J. Korea Technol. Innov. Soc. 2018, 21, 522-559.

33. Shadish, W.R.; Haddock, C.K. Combining estimates of effect size. In The Handbook of Research Synthesis; Cooper, H., Hedges, L.V., Eds.; Russell Sage Foundation: New York, NY, USA, 1994.

34. Huedo-Medina, T.B.; Sanchez-Meca, J.; Marin-Martinez, F.; Botella, J. Assessing heterogeneity in meta-analysis: I2 or Q statistic? Psychol. Methods 2006, 11, 193-206. [CrossRef]

35. Cohen, J. Statistical Power Analysis for the Behavioral Science, 2nd ed.; Lawrence Erlbaum Associates: Mahwah, NJ, USA, 1988.

36. Kim, J.; Kim, M.; Park, H. A Meta-analysis on Antecedents and Consequences of Technological Innovation: Focused on Empirical Analyses of South Korea's SMEs. Asia Pacific J. Small Bus. 2020, 42, 43-67. [CrossRef]

37. Rosenbusch, N.; Brinckmann, J.; Bausch, A. Is innovation always beneficial? A meta-analysis of the relationship between innovation and performance in SMEs. J. Bus. Ventur. 2011, 26, 441-457. [CrossRef]

38. Audretsch, D.B.; Elston, J.A. Can institutional change impact high-technology firm growth?: Evidence from Germany's Neuer Markt. J. Product. Anal. 2006, 25, 9-23. [CrossRef]

39. Classen, N.; Carree, M.; van Gils, A.; Peters, B. Innovation in family and non-family SMEs: An exploratory analysis. Small Bus. Econ. 2014, 42, 595-609. [CrossRef]

40. Rant, M.B.; Cerne, S.K. Becoming a Hidden Champion: From Selective use of Customer Intimacy and Product Leadership to Business Attractiveness. South East Eur. J. Econ. Bus. 2017, 12, 89-103. [CrossRef]

41. Gruenwald, R.K. Causes of High-Growth of Small- and Mid-Cap Companies in the DACH Countries. Ph.D. Thesis, Uniwersytet Ekonomiczny W Krakowie, Kraków, Poland, 2016. 
42. Bartz, W.; Winkler, A. Flexible or fragile? The growth performance of small and young businesses during the global financial crisis-Evidence from Germany. J. Bus. Ventur. 2016, 31, 196-215. [CrossRef]

43. Rammer, C.; Czarnitzki, D.; Spielkamp, A. Innovation success of non-R\&D-performers: Substituting technology by management in SMEs. Small Bus. Econ. 2009, 33, 35-58. [CrossRef]

44. Schäfer, D.; Stephan, A.; Mosquera, J.S. Family ownership: Does it matter for funding and success of corporate innovations? Small Bus. Econ. 2017, 48, 931-951. [CrossRef]

45. Rammer, C.; Schmiele, A. Driver and Effects of Internationalizing Innovation by SMEs; Discussion Paper No. 08-035; ZEW-Centre for European Economic Research: Mannheim, Germany, 2008.

46. Almus, M.; Czarnitzki, D. The effects of public R and D subsidies on firms' innovation activities: The case of Eastern Germany. J. Bus. Econ. Stat. 2003, 21, 226-236. [CrossRef]

47. Harms, R. A Multivariate Analysis of the Characteristics of Rapid Growth Firms, Their Leaders, and Their Market. J. Small Bus. Entrep. 2009, 22, 429-454. [CrossRef]

48. Hertel, M.; Menrad, K. Adoption of energy-efficient technologies in German SMEs of the horticultural sector-the moderating role of personal and social factors. Energy Effic. 2016, 9, 791-806. [CrossRef]

49. Müller, E.; Zimmermann, V. The importance of equity finance foR R\&D activity. Small Bus. Econ. 2009, 33, 303-318. [CrossRef]

50. Czarnitzki, D.; Delanote, J. R\&D policies for young SMEs: Input and output effect. Small Bus. Econ. 2015, 45, 465-485.

51. Block, J.H.; Marcus, W. Necessity and opportunity entrepreneurship in Germany: Characteristics and Earning Differentials. Necessity Entrep. 2010, 62, 154-174.

52. Andries, P.; Czarnitzki, D. Small firm innovation performance and employee involvement. Small Bus. Econ. 2014, 43, 21-38. [CrossRef]

53. Harms, R.; Wagner, M.; Glauner, W. Relating Personal, Firm-based and Environmental Factors to the Monetary and Temporal Engagement in Corporate Social Responsibility in German Gazelles. J. Small Bus. Entrep. 2010, 23, 195-210. [CrossRef]

54. Calabrò, A.; Campopiano, G.; Basco, R. Principal-principal conflicts and family firm growth: The moderating role of business family identity. J. Fam. Bus. Manag. 2017, 7, 291-308. [CrossRef]

55. Steeger, J.H.; Hoffmann, M. Innovation and family firms: Ability and willingness and German SMEs. J. Fam. Bus. Manag. 2016, 6, 251-269. [CrossRef]

56. Ahn, S.; Kim, J.; Kim, J.; Technology, K.; Society, I. The Effect of Public R\&D Support on R\&D Investment of Korean Medium-sized Firms. J. Korea Technol. Innov. Soc. 2017, 20, 546-575.

57. Oh, C.H. A Study on the Effects of Alliance Capability on Cooperative RED Activities' Performance: Alliance Capability Drivers; The Graduate School Korea University of Technology Education Cooperative: Seoul, Korea, 2013.

58. Jeon, K.-H.; Ha, S.-T.; Park, J.-E.; Park, M.-K. The Effect of Corporate Innovation Activities and Government Policy on Corporate Outcomes: Focusing on Small and Medium Enterprises. Korean Account. J. 2018, 27, 295-323. [CrossRef]

59. Jeon, J.Y. A Study on the RED Cooperation Characteristics and Innovation Performance of SMEs; Graduate School of Konkuk University: Seoul, Korea, 2018.

60. Jung, G. Impact of Internal Marketing Factorson Technological Innovation in Organizations and Perceived Service Quality; Graduate School, Daejeon University: Daejeon, Korea, 2015.

61. Jung, J.-H.; Kim, J.-S.; Choi, K.; Lee, B.-H. Effectiveness of Government R\&D on Firms R\&D Spending. J. Korea Contents Assoc. 2016, 16, 150-162.

62. Jung, J. Effectiveness of Government RED Subsidies on RED Investment of Each Type of Firm; University of Science and Technology: Seoul, Korea, 2017.

63. Hwang, S.-W. The Effect of RED Capabilities, Financial Stability and Internationalization on the Business Performance of Medium-Large Enterprise Focusing on Panel Analysis of Manufacturing Industry; Graduate School of Konkuk University: Seoul, Korea, 2017.

64. Kim, D.-E.; Jeong, J.-H.; Lee, C.; Min, Y.-K. Determinants of R\&D Capability of Mid-Sized DomesticExport Companies: Firm Level, Market Level, Government Level. Int. Bus. Rev. 2021, 24, 197-209.

65. Kim, D.-E. Empowering Factors of Corporate Technology Planning Capabilities: Focusing on Small and Medium-Sized Companies. Korean Manag. Consult. Rev. 2021, 21, 441-450.

66. Min, Y.; Jeong, J.; Lee, C.; Kim, D. The Effect of Government R\&D Support Programs on R \& D Investment and Innovation Performance in Korean Medium Sized Enterprises. Korean Manag. Rev. 2021, 50, 173-195.

67. Oh, H.; Choi, G. Economic Performance Anaiysis of Public Support for Technology Innovation-led Enterprises: Focused on World Class 300 Project. Asia-Pacific J. Bus. Ventur. Entrep. 2020, 15, 121-133.

68. Woo, K.H.; Park, B.J.; Park, S.Y. The Impact of the Capabilities of R\&D Intensive Firms on Export Performance: Focusing on SMEs and Mid-sized Firms. Asia-Pacific J. Bus. Ventur. Entrep. 2016, 11, 167-178.

69. Lee, B. An Empirical Study of the Impacts of Open Innovation of SMEs and HPE on Business Performance. J. Ind. Econ. Bus. 2014, $27,2483-2511$.

70. Lee, J.L.; Sim, J.; Lim, C.-L.; Jung, W.-J. Impact of Government R\&D Support on the Performance of Middle Market Enterprises. J. Korea Technol. Innov. Soc. 2021, 24, 139-160.

71. Hyun, Y.S.; Lee, B.H.; Lee, J.S. The impact of technology acquisition strategy on firm performance in Korean Medium size Enterprises. Asia-Pacific J. Bus. Ventur. Entrep. 2013, 8, 1-16.

72. Hong, W.S.; Kim, H.J. The Impact of Technological Innovation Activities on Firm Growth. Sci. Technol. Policy 2018, 1, 63-86. 